\title{
プロテオミクスで解き明かすミトコンドリアからのシトクロム $\mathrm{c}$ 放出機構
}

\author{
山本武範, ${ }^{*}, a$ 山田安希子, $b$ 吉村勇哉,,$a c$ 寺田 $\quad$ 弘, ${ }^{d}$ 篠原康雄 $a, c$
}

\section{The Mechanisms of the Release of Cytochrome c from Mitochondria Revealed by Proteomics Analysis}

\author{
Takenori Yamamoto, ${ }^{*, a}$ Akiko Yamada, ${ }^{b}$ Yuya Yoshimura, ${ }^{a, c}$ \\ Hiroshi Terada, ${ }^{d}$ and Yasuo Shinohara ${ }^{a, c}$ \\ ${ }^{a}$ Institute for Genome Research; ${ }^{b}$ Institute of Health Biosciences, University of Tokushima; \\ 3-18 Kuramoto-cho, Tokushima 770-8503, Japan: 'Faculty of Pharmaceutical Science, \\ University of Tokushima; 1-78 Shomachi, Tokushima 770-8505, Japan: and \\ ${ }^{d}$ Faculty of Pharmaceutical Sciences, Tokyo University of Science; \\ 2641 Yamazaki, Noda, Chiba 278-8510, Japan.
}

(Received July 4, 2012)

\begin{abstract}
Mitochondrial permeability transition (PT) is the phenomenon in which the mitochondrial inner membrane becomes permeable to various solutes and ions. When PT is induced by $\mathrm{Ca}^{2+}$, cytochrome $\mathrm{c}$ is released from mitochondria into the cytosol where it then triggers subsequent steps of programmed cell death, apoptosis. Thus, the proteins that regulate PT and cytochrome c release could become druggable targets for various diseases. However, the mechanisms of PT and the release of cytochrome $\mathrm{c}$ have not yet been revealed. We previously showed that valinomycin, a potassium selective ionophore, also caused release of cytochrome $\mathrm{c}$ from mitochondria without inducing PT. This result indicates that cytochrome $\mathrm{c}$ could be released from mitochondria with or without induction of PT. In this study, to understand the difference of effects of valinomycin and $\mathrm{Ca}^{2+}$ on mitochondria, we examined what protein species are released from valinomycin- and $\mathrm{Ca}^{2+}$-treated mitochondria by LC-MS/MS. As a result, only the proteins located in the intermembrane space were found to be released from valinomycin-treated mitochondria, while those in both the intermembrane space and in the matrix were released from $\mathrm{Ca}^{2+}$-treated mitochondria. Furthermore, the protein releases by each reagent occurred not selectively but in a concentration-dependent manner. Based on these results, the permeabilization effects of $\mathrm{Ca}^{2+}$ and valinomycin on the inner and outer mitochondrial membranes are discussed.
\end{abstract}

Key words_— cytochrome c; mitochondria; permeability transition; proteomics; release

\section{1. はじめに}

ミトコンドリアは真核生物に存在する細胞小器官 であり，その主たる機能はエネルギー変換である. 生体が摂取した様々な栄養分子のエネルギーはミト コンドリアにおいて生体エネルギー通貨である ATP に変換される.この変換の仕組みはミトコン ドリアが持つ 2 種類の膜のうち内膜に存在してお

The authors declare no conflict of interest.

$a$ 徳島大学疾患ゲノム研究センター, $b$ 同大学院ヘルス バイオサイエンス研究部（テ770-8503 徳島市蔵本町 3-18), c徳島大学薬学部(干770-8505 徳島市庄町 1-78), $d$ 東京理科大学薬学部（テ278-8510 千葉県野田市山崎 2641)

*e-mail: tyamamo@genome.tokushima-u.ac.jp 本総説は, 日本薬学会第 132 年会シンポジウム S06 で 発表したものを中心に記述したものである.
り，内膜では栄養分子の持つエネルギーを一旦内膜 を介した $\mathrm{H}^{+}$の電気化学ポテンシャル差に置き換 え，このポテンシャル差を駆動力としてマトリック ス内で ATP が合成される。このような ATP 合成 を効率的に行うため, 通常ミトコンドリア内膜の物 質透過性は極めて低く保たれている。しかしなが ら，ミトコンドリアに過剩量の $\mathrm{Ca}^{2+}$ が取り込まれ ると, 内膜の物質透過性が非選択的に上昇する「透 過性遷移（permeability transition: PT)」と呼ばれ る現象が引き起こされる（Fig. 1)。透過性遷移は, それが誘起されたミトコンドリアで膨潤や ATP 合 成阻害が起こるといつた現象としての理解は早くか ら進んでいたものの，その生理的な意義については 長らく不明であった。近年, 透過性遷移が誘起され たミトコンドリアからシトクロム c というタンパク 
質が漏出し，漏出したシトクロム c が細胞死実行の 引き金を引くことが明らかにされたことから，にわ かに透過性遷移の細胞死制御への関与がクローズア ップされてきた. ${ }^{1-3)} し か し ， \mathrm{Ca}^{2+}$ がどのように内 膜の透過性を上昇させるのか？ またこのときシト クロム c がどのように外膜を透過してミトコンドリ アから漏出するのか？ といつた疑問についてはい まだ解答が得られていない。

これらの疑問に対して突破口を見い出すべく，わ れわれはこれまでに $\mathrm{Ca}^{2+}$ 以外にどのような化合物

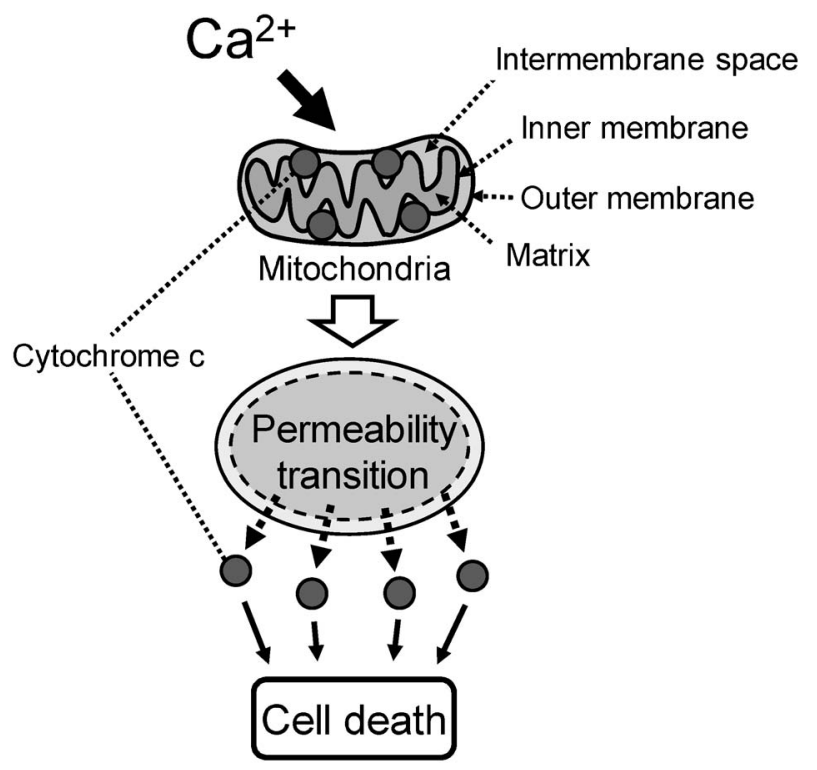

Fig. 1. Mitochondrial Permeability Transition and Cytochrome c Release from Mitochondria

When mitochondrial permeability transition (PT) is induced $\mathrm{by} \mathrm{Ca}^{2+}$, cytochrome $\mathrm{c}$ present in the intermembrane space of mitochondria is released. The released cytochrome $\mathrm{c}$ triggers subsequent steps of apoptosis.
が透過性遷移やそれに伴うシトクロム c 漏出を引き 起こすのか，またそれらの化合物に共通する性質は どのようなものかという観点から研究を進めてき た。 その結果, $\mathrm{Ca}^{2+}$ 以外にも様々な化合物がミト コンドリアからシトクロム $\mathrm{c}$ を漏出させることを明 らかにした. ${ }^{4-6)}$ その中でも，特にカリウム選択的 イオノフォアとして知られるバリノマイシンが，透 過性遷移を誘起することなくミトコンドリアからシ トクロム $\mathrm{c}$ を漏出させるという興味深い知見を見い

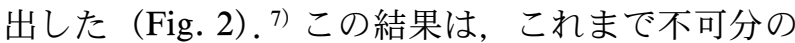
関係であると考えられてきたシトクロム $\mathrm{c}$ 漏出と透 過性遷移という 2 つ現象は実は切り離して考える ことができることを意味しており，シトクロム $\mathrm{c}$ 漏 出機構に多様性があることを示すものであった。こ のことから，バリノマイシンと $\mathrm{Ca}^{2+}$ がミトコンド リア膜に及ぼす作用の違いを理解することが，シト クロム $\mathrm{c}$ の漏出機構解明への糸口となると考えられ た. $\mathrm{Ca}^{2+}$ により透過性遷移を伴ってシトクロム $\mathrm{c}$ が漏出する場合と，バリノマイシンにより透過性遷 移を伴わずにシトクロム c が漏出する場合とでは, ミトコンドリア内膜の状態が全く異なることから， 漏出するタンパク質の分子種にも違いがあるであろ うことは容易に予想された。 そこで本研究では，バ リノマイシン又は $\mathrm{Ca}^{2+}$ を添加したミトコンドリア から漏出するタンパク質をプロテオミクス解析によ り網羅的に同定し，漏出されるタンパク質種の違い から両ミトコンドリアで起きている現象を分子レベ ルで理解することを試みた。

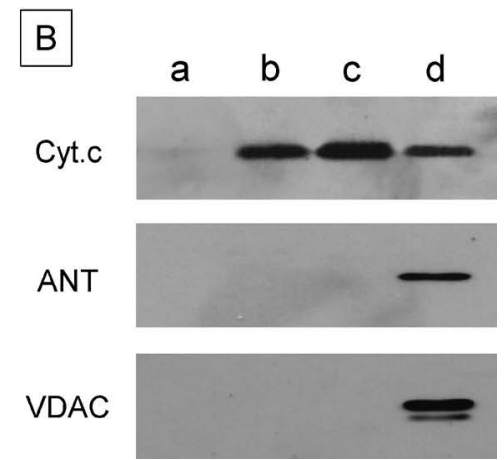

Fig. 2. Effects of Valinomycin and $\mathrm{Ca}^{2+}$ on Mitochondrial Configuration and Localization of Various Proteins

A. Transmission electron microscopic appearance of non-treated mitochondria (a), valinomycin-treated mitochondria (b), and $\mathrm{Ca}^{2+}$-treated mitochondria (c) are shown. After each treatment, mitochondria were promptly harvested and subjected to the fixation processes. Bar under photograph "c" indicates $1 \mu \mathrm{m}$. B. For lanes a-d, supernatants $(15 \mu \mathrm{L} /$ lane $)$ of non-treated, valinomycin-treated, and $\mathrm{Ca}^{2+}$-treated mitochondria, or whole proteins of rat liver mitochondria (5 $\left.\mu \mathrm{g} / \mathrm{lane}\right)$, respectively, were subjected to SDS-PAGE. After separation, proteins were transferred to nitrocellulose membranes. Membranes thus prepared were incubated with specific antibodies against cytochrome c (Cyt.c), adenine nucleotide translocase (ANT) or voltage-dependent anion channel (VDAC). 


\section{2. 漏出タンパク質のプロテオミクス解析}

プロテオミクス（proteomics）とは，広義には 「タンパク質全体（プロテオーム； proteome）を観 察することを通して, 生命機能の解明を目指す研 究」を意味する.このプロテオミクスにおいて中核 となるプロセスは, 質量分析による大規模なタンパ ク質の分子同定である。すすなわち，質量分析により 得られたタンパク質の質量情報を, 膨大なゲノム情 報から導き出されるタンパク質分子の質量情報と照 合することによって，サンプル中に存在するタンパ ク質の分子種を特定するのである。近年，プロテオ ミクス解析は質量分析装置の高精度化と操作の簡便 化によって分野を問わず広く行われるようになって きた. われわれはこのプロテオミクス解析によって ミトコンドリアから漏出するタンパ質の網羅的な分 子同定を試みた。

まず，ラットの肝臓から単離したミトコンドリア をメディウム中でインキュベートし，ここにバリノ マイシンを添加した場合にミトコンドリアから漏出 するタンパク質について Liquid chromatographytandem mass spectrometry（LC-MS/MS）によって

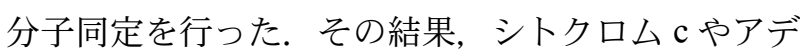
ニレートキナーゼ 2 を始めとする複数の膜間腔に存 在するタンパク質が同定された（Table 1)。これに 対し， $\mathrm{Ca}^{2+}$ を添加した場合には，膜間腔に存在す るタンパク質に加え, マトリックス内に存在する夕 ンパク質も同定された (Table 2)。これらの結果か ら，バリノマイシンを添加したミトコンドリアでは 外膜のみの透過性が上昇するのに対し, $\mathrm{Ca}^{2+}$ を添 加した場合には内膜と外膜ともに透過性が上昇した 状態となっていることが明らかになった。

3. ミトコンドリアからのタンパク質の漏出様式

では，ここで明らかになったバリノマイシンや $\mathrm{Ca}^{2+}$ の作用によって引き起こされるタンパク質の
漏出は分子種選択的に起こっているのであろうか？ われわれはこの疑問に対しても，プロテオミクスを 駆使したアプローチを試みた。すなわち，仮にミト コンドリアから “非選択的”に漏出が起きているな らば漏出したタンパク質の分子種は本来ミトコンド リアに豊富に存在するタンパク質種と合致し，逆に “選択的”にタンパク質の漏出が起きているのなら ば両者に相関は認められないと考えられる.

そこで，まずミトコンドリアに豊富に存在する夕 ンパク質をリスト化するため, ミトコンドリアの総 タンパク質を質量分析に供し，無差別に約 100 種の タンパク質を同定した。一般に，質量分析によりタ ンパク質の分子同定を行った場合，含量の多いタン パク質からおよそ優先的に同定が行われていくた め，われわれが同定した約 100 種のタンパク質は, 700 種類以上とも言われるミトコンドリアを構成す るタンパク質の中でも比較的豊富に存在するタンパ ク質であると考えることができる. ${ }^{8)}$ そこで，ここ で同定されたタンパク質をミトコンドリアに豊富に 存在するタンパク質群として，バリノマイシン又は $\mathrm{Ca}^{2+}$ を添加した場合にミトコンドリアから漏出し たタンパク質群との照合を行った。 その結果，漏出 したタンパク質種のほぼすべてがミトコンドリアに 豊富に存在するタンパク質種と合致した。このこと から，バリノマイシン又は $\mathrm{Ca}^{2+}$ の添加によって漏 出したタンパク質は，いずれも“分子種非選択的” にミトコンドリアから漏出していることが分かっ た.このことに加え，漏出したタンパク質の中には $100 \mathrm{kDa}$ を超えるような巨大なタンパク質も含まれ ていたことから，バリノマイシンを添加した場合に は外膜で, $\mathrm{Ca}^{2+}$ を添加した場合には外膜と内膜で 壊裂が起きていることが強く示唆される。したがつ て，シトクロム $\mathrm{c}$ は壊裂した外膜の亀裂から他の夕 ンパク質とともに細胞質に漏出してくるものと考え

Table 1. LC-MS/MS Analysis of Proteins Released from Valinomycin-treated Mitochondria

\begin{tabular}{l|c|c|c}
\hline \hline \multicolumn{4}{c}{ Identified Protein } \\
\hline Name & $\mathrm{AC}^{\mathrm{a})}$ & $\mathrm{Mw}^{\mathrm{b}}$ & Localization \\
\hline Sulfite oxidase & $\mathrm{Q} 07116$ & 55 & Intermembrane space \\
\hline Adenylate kinase isoenzyme 2 & $\mathrm{P} 29410$ & 27 & Intermembrane space \\
\hline Cytochrome c & $\mathrm{P} 62898$ & 12 & Intermembrane space \\
\hline
\end{tabular}

a) Accession number in UniProt, b) Molecular weight. 
Table 2. LC-MS/MS Analysis of the Proteins Released from $\mathrm{Ca}^{2+}$-treated Mitochondria

\begin{tabular}{|c|c|c|c|}
\hline \multicolumn{4}{|c|}{ Identified Protein } \\
\hline Name & $\mathrm{AC}$ a) & $M w^{b)}$ & Localization \\
\hline Carbamoyl-phosphate synthase & P07756 & 166 & Matrix \\
\hline Pyruvate carboxylase & P52873 & 130 & Matrix \\
\hline Dimethylglycine dehydrogenase & Q63342 & 96 & Mitochondria \\
\hline Aconitate hydratase & Q9ER34 & 86 & Mitochondria \\
\hline Glutamate dehydrogenase 1 & P10860 & 62 & Matrix \\
\hline Methylmalonate-semialdehyde dehydrogenase & Q02253 & 58 & Matrix \\
\hline Aldehyde dehydrogenase & P11884 & 57 & Matrix \\
\hline Hydroxymethylglutaryl-CoA synthase & P22791 & 57 & Matrix \\
\hline Sulfite oxidase & Q07116 & 55 & Intermembrane space \\
\hline Dihydrolipoyl dehydrogenase & Q63342 & 55 & Matrix \\
\hline Aspartate aminotransferase & P00507 & 48 & Matrix \\
\hline Long-chain specific acyl-CoA dehydrogenase & P15650 & 48 & Matrix \\
\hline Medium-chain specific acyl-CoA dehydrogenase & P08503 & 47 & Matrix \\
\hline Acetyl-CoA acetyltransferase & P17764 & 45 & Mitochondria \\
\hline Short-chain specific acyl-CoA dehydrogenase & $\mathrm{P} 15651$ & 45 & Matrix \\
\hline 3-ketoacyl-CoA thiolase & $\mathrm{P} 13437$ & 42 & Mitochondria \\
\hline Ornithine carbamoyltransferase & $\mathrm{P} 00481$ & 40 & Matrix \\
\hline Malate dehydrogenase & P04636 & 36 & Matrix \\
\hline 2,4-dienoyl-CoA reductase & Q64591 & 36 & Mitochondria \\
\hline 3-hydroxyisobutyrate & P29266 & 36 & Mitochondria \\
\hline Electron transfer flavoprotein subunit alpha & $\mathrm{P} 13803$ & 35 & Matrix \\
\hline Hydroxymethylglutaryl-CoA lyase & P97519 & 35 & Matrix \\
\hline Thiosulfate sulfurtransferase & P24329 & 33 & Matrix \\
\hline Enoyl-CoA hydratase & $\mathrm{P} 14604$ & 32 & Matrix \\
\hline 3,2-trans-enoyl-CoA isomerase & P23965 & 32 & Matrix \\
\hline Electron transfer flavoprotein subunit beta & Q68FU3 & 28 & Matrix \\
\hline Adenylate kinase isoenzyme 2 & P29410 & 27 & Intermembrane space \\
\hline Adenylate kinase isoenzyme 4 & Q9WUS0 & 25 & Matrix \\
\hline Cytochrome c & P62898 & 12 & Intermembrane space \\
\hline $10 \mathrm{kDa}$ heat shock protein & P26772 & 11 & Matrix \\
\hline
\end{tabular}

a) Accession number in UniProt, b) Molecular weight.

\section{られる. ${ }^{9)}$}

しかしながら, $\mathrm{Ca}^{2+}$ やバリノマイシンを添加し たミトコンドリアでなぜ外膜の壊裂が起きるのかと いう次なる疑問が浮上してくる。この点についてい まだ明確な解答は得られていないが， $\mathrm{Ca}^{2+}$ を添加 したミトコンドリアではマトリックス領域の膨張が
認められることから, ${ }^{10)}$ この膨潤によって外膜が物 理的に壊裂するというモデルが考えられる。，一方， バリノマイシンを添加したミトコンドリアでは $\mathrm{Ca}^{2+}$ の場合のように大きな膨潤は認められないこ とから，その外膜を壊裂させるメカニズムに興味が 持たれる. 


\section{4. 呼吸基質非存在下のミトコンドリアにおける} シトクロム $\mathrm{c}$ の挙動の解析

ここまでの解析から， シトクロム c がミトコンド リアから漏出するとき，外膜の透過性が分子種非選 択的に六進していることが分かった。 では，単に外 膜の透過性が亢進すればシトクロム c はミトコンド リア外に漏出されるのであろうか? この疑問に対 する解答を得るため，われわれは様々な条件下のミ トコンドリアに $\mathrm{Ca}^{2+}$ を添加してそのときのシトク ロム c の挙動を解析した。その結果，ミトコンドリ ア内膜に電気化学ポテンシャル差を形成するために 必要なコハク酸のような呼吸基質をメディウムに添 加しなかった場合, $\mathrm{Ca}^{2+}$ によって透過性遷移は誘 起されるにもかかわらず（Fig. 3)，ミトコンドリ アからのシトクロム $\mathrm{c}$ 漏出は認められないことが明 らかになった（Fig. 4). またこのとき，シトクロ 厶 $\mathrm{c}$ の約 2 倍の分子量を有し膜間腔に存在するアデ ニレートキナーゼ 2 はミトコンドリア外にすべて漏 出していた。このことから，呼吸基質非存在下で透 過性遷移が誘起されたミトコンドリアでも外膜の透 過性は十分に立進するものの，このときなぜかシト クロム $\mathrm{c}$ は漏出しないことが分かった.

以上のことから，ミトコンドリアからシトクロム c が漏出するためには, $\mathrm{Ca}^{2+}$ やバリノマイシンの ような外的な刺激によって外膜の透過性が充進する だけでは不十分であること, シトクロム c の漏出を 制御している未知の機構が存在しこの機構に呼吸基 質が関与していることが示唆された．多くの参考書 の中で，シトクロム $\mathrm{c}$ はミトコンドリアの膜間腔に 存在していると記載されているが，実際にはシトク 口ム $\mathrm{c}$ は内膜の細胞質側表面に静電引力で弱く結合 した状態で存在している.このことから，シトクロ ム c がミトコンドリアから漏出するにはまず内膜か ら解離する必要があり,この解離のプロセスに呼吸 基質が関与しているのかもしれない. ${ }^{11)}$

\section{5. おわりに}

シトクロム c がミトコンドリアから漏出すると き，膜間腔に存在するシトクロム $\mathrm{c}$ がごのように外 膜を透過するのかという疑問に対し，これまで大き く2つの仮説が立てられていた，1つは，シトクロ 厶 $\mathrm{c}$ を透過させる巨大なチャネルが外膜に形成され るという説，もう 1 つは外膜の壊裂によるという説 である．われわれが今回の研究から得た知見は後者

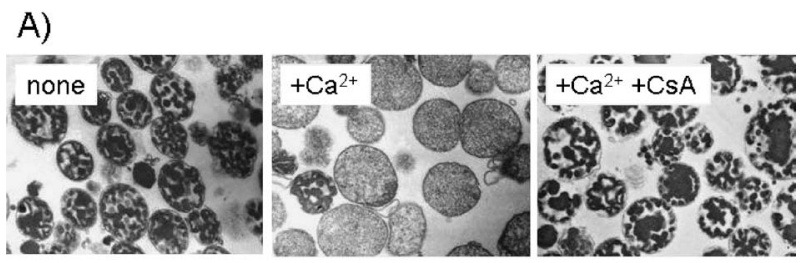

B)

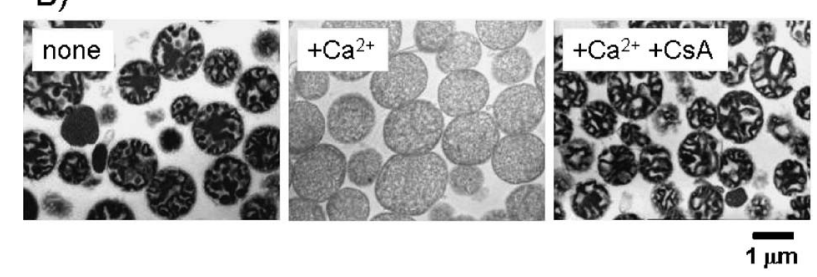

Fig. 3. Morphological Changes in Mitochondria Examined by Transmission Electron Microscopy and Release Analysis of Cytochrome $\mathrm{c}$ from Mitochondria

Photographs in panels $\mathrm{A}$ and $\mathrm{B}$ represent the morphologies of mitochondria observed in the presence and absence, respectively, of the respiratory substrate (succinate). When used, $5 \mathrm{~mm}$ succinate (plus $0.5 \mu \mathrm{g}$ rotenone/mg mitochondrial protein) was included in the incubation medium. Photos labeled "none" show the morphology of non-treated mitochondria; and those labeled " $+\mathrm{Ca}^{2+}$ " and " $+\mathrm{Ca}^{2+}+\mathrm{CsA}$," the morphology of mitochondria treated with $100 \mu \mathrm{M} \mathrm{Ca}{ }^{2+}$ and with $100 \mu \mathrm{M} \mathrm{Ca}^{2+}$ plus $2.5 \mu \mathrm{M}$ CsA, respectively. Bar indicates $1 \mu \mathrm{m}$ for all photos. CsA: cyclosporine A; PT inhibitor.

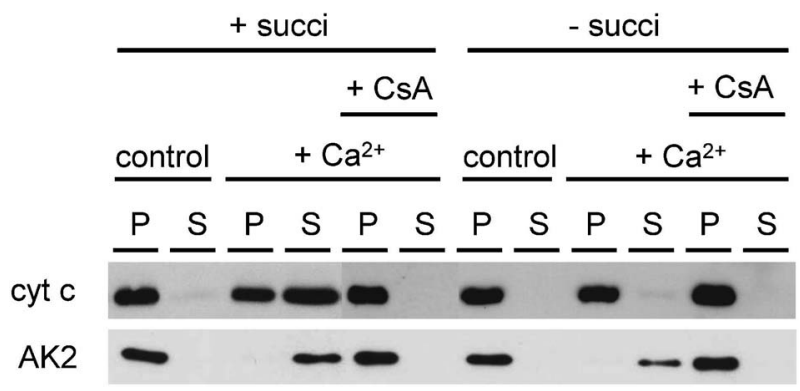

Fig. 4. Release Analysis of Cytochrome $\mathrm{c}$ and Adenylate Kinase 2 from Mitochondria Treated with $\mathrm{Ca}^{2+}$ in the Presence or Absence of Respiratory Substrate

For examination of the effects of $\mathrm{Ca}^{2+}$ treatment of mitochondria in the presence or absence of succinate on the release of cytochrome $\mathrm{c}$ and adenylate kinase 2, mitochondria incubated under either condition were promptly centrifuged. The pellet $(\mathrm{P})$ and supernatant $(\mathrm{S})$ thus obtained from individual mitochondrial suspensions were subjected to SDS-PAGE followed by immuno-detection of cytochrome $\mathrm{c}$ and adenylate kinase 2 (AK2). $\mathrm{Ca}^{2+}$ and CsA were added to final concentrations of $100 \mu \mathrm{M}$ and $2.5 \mu \mathrm{M}$, respectively. CsA: cyclosporine A; PT inhibitor.

の膜壊裂説を強く支持するものであった．しかしな がら，膜の壊裂を起こし外膜の透過性を上昇させる ことがシトクロム $\mathrm{c}$ をミトコンドリアから漏出させ る分子機構のすべてではなく，それ以外にも呼吸基 質が関与する未知の制御因子が存在することが示唆 される，今後これらの因子が同定され，シトクロム $\mathrm{c}$ 漏出機構の全貌が解き明かされることを期待して 
いる.

\section{REFERENCES}

1) Zoratti M., Szabo I., Biochim. Biophys. Acta, 1241, 139-176 (1995).

2) Bernardi P., Colonna R., Costantini P., Eriksson O., Fontaine E., Ichas F., Massari S., Nicolli A., Petronilli V., Scorrano L., Biofactors, 8, 273-281 (1998).

3) Kroemer G., Reed J. C., Nat. Med., 6, 513519 (2000).

4) Shinohara Y., Bandou S., Kora S., Kitamura S., Inazumi S., Terada H., FEBS Lett., 428, 89-92 (1998).

5) Yamamoto T., Tachikawa A., Terauchi S., Yamashita K., Kataoka M., Terada H., Shinohara Y., Eur. J. Biochem., 271, 3573-3579 (2004).

6) Yamamoto T., Terauchi S., Tachikawa A., Yamashita K., Kataoka M., Terada H., Shino- hara Y., J. Bioenerg. Biomembr., 37, 299-306 (2005)

7) Shinohara Y., Almofti M. R., Yamamoto T., Ishida T., Kita F., Kanzaki H., Ohnishi M., Yamashita K., Shimizu S., Terada H., Eur. J. Biochem., 269, 5224-5230 (2002).

8) Forner F., Foster L. J., Campanaro S., Valle G., Mann M., Mol. Cell. Proteomics, 5, 608619 (2006).

9) Yamada A., Yamamoto T., Yamazaki N., Yamashita K., Kataoka M., Nagata T., Terada H., Shinohara Y., Mol. Cell. Proteomics, 8, 1265-1277 (2009)

10) Terauchi S., Yamamoto T., Yamashita K., Kataoka M., Terada H., Shinohara Y., Mitochondrion, 5, 248-254 (2005).

11) Yamamoto T., Yoshimura Y., Yamada A., Gouda S., Yamashita K., Yamazaki N., Kataoka M., Nagata T., Terada H., Shinohara Y., J. Bioenerg. Biomembr., 40, 619-623 (2009). 